\title{
Albergo Diffuso (Diffused/Distributed Hotel): Case Study of Slovenia
}

\author{
Saša Zupan Korže \\ Vanadis d.o.o., Slovenia \\ sasa.zupan@vanadis.si
}

In the second decade of the 21st century, Albergo Diffuso (AD), a new type of tourist accommodation, which originated in Italy, emerged in other countries of Europe, e.g. in Croatia, Switzerland, Slovenia and others. The purpose of this paper is to set out an in-depth understanding of how AD is understood in Italy and to present the evolutionary path of ADS in Slovenia. The goals of the research are (a) to point out the key characteristics of AD, its structural and legal features as implemented in Italy, (b) to compare $\mathrm{AD}$ to a traditional hotel and (c) to present the first Slovenian $\mathrm{AD}$ with some related legal and organisational considerations. The research started in June and was completed in December 2017. A number of different qualitative methods were used in the process of data collection (review of existing literature, websites, regulations and four in-depth semi-structured interviews, two site-observations) and data processing (description, compilation, comparison, analysis, interpretation). The limited amount of available data was the prime reason for the use of a descriptive type of research. Results of the study are presented according to the research goals. Firstly, the results show that ADS in Italy are understood to be a formal subtype of hotel with the following characteristics: with deep ties to the surrounding territory and the local culture, with some special physical features and a hospitality service that distinguishes them from traditional hotels and other traditional types of private tourist accommodations. Secondly, several initiatives for creating ADS in Slovenia started after 2010; however, only one was realised: in December 2017 the first AD, Konjice, was opened, even though official tourism documents in Slovenia are still overlooking the concept. The contribution of the paper is to provide insight into the evolution of AD in Italy and to present the evolution of ADS in Slovenia despite the gap between the strategic approach of Slovene tourism policy makers and the private tourism sector. ADS are a somewhat new research topic. There are some research studies about ADs in Italy and Croatia, but none about ADS in Slovenia. This paper represents the first step in filling this gap, which calls for further studies on ADs in Slovenia.

Keywords: Albergo Diffuso (AD), diffused/dispersed hotels (DH), scattered hotels, legal framework, organisational issues

https://doi.org/10.26493/2335-4194.11.43-56

\section{Introduction}

Tourist accommodations (тAсs) are various functionally designed spaces used by travellers for tempo- rary stays: hotels, motels, private rooms, apartments, campsites, etc. There are some key facts about TACS evident from current theory and practice. Firstly, TACS 
differ from each other according to the technical characteristics, content and quality of their facilities and services (Vallen \& Vallen, 2013; Cerović, 2010). Secondly, due to different cultural, geographical and historical characteristics of individual countries, the criteria for TAC classification vary among countries. Thirdly, countries differ from each other with respect to whether TACs are (or are not) regulated by the state. Fourthly, there are types of TACs that are specific for certain countries, e.g. paradores in Spain (http: //www.paradores-spain.com), pousadas in Portugal (https://www.pousadas.pt), Albergo Diffuso in Italy (http://www.alberghidiffusi.it), and diffused and integrated hotels in Croatia ('Pravilnik o razvrstavanju, kategorizaciji i posebnim standardima ugostiteljskih objekata iz skupine hoteli', 2016).

Since the turn of the millennium, new forms/types of TACs have been created: e.g. glamping, tree houses, ice rooms, 'capsules' etc. (Page \& Connell, 2014). Some of them are - due to their innovative design - difficult to classify according to standard criteria. In Slovenia, innovative developments in the field of TACS has been evident in Garden Village in Bled (https: //gardenvillagebled.com), Herbal in Ljubno (http:// www.charmingslovenia.com), Ecoresort beneath Velika Planina (http://sloveniaecoresort.com), and others. Slovenian TACS of this new era are innovative in the functional arrangement of their accommodation units or in their comprehensive, holistic hospitality facilities and services. Officially, they are classified according to Slovenian regulations. However, for marketing purposes they use - instead of an official TAC type - terms that briefly indicate their facilities and services (e.g. tourist ecological complex, glamping resort, etc.). Guests reward their service with excellent reviews (see, e.g., https://www.booking.com or https: //www.tripadvisor.com).

Different types of TAC meet the requirements of the different target niches of tourists. Experience from ADS in Italy indicates that ADs have specific characteristics that are particularly attractive to a certain niche of traveller. This paper aims to explore them and to investigate its potentials in Slovenia.

In this paper, we present the answers to the following research questions:
1. What was the evolution path of ADS in Italy from the initial idea until the present?

2. How has the idea of AD evolved in Slovenia?

3. What are the organisational and legal frameworks for AD in Slovenia?

\section{Theoretical Background}

\section{Terminology}

$\mathrm{AD}$ is an Italian phenomenon (Confalonieri, 2011) and a relatively new research topic (Presenza, Yucelen, \& Camillo, 2016; Russo, Lombardi, \& Mangiagli, 2013). Thus, the amount of research is rather limited, particularly that of a quantitative nature. Most existing research studies on $\mathrm{AD}$ are qualitative and geographically limited, mostly to Italy and Croatia.

The review of existing literature revealed some different approaches of scholars and practitioners to the topic, e.g. use of different terms when the Italian term 'A D' is translated to English, different viewpoints of researching AD, etc.

In the existing literature, there are several different translations of 'AD:' 'diffuse hotels' (Županović, 2015), 'diffused hotels' (Đurkin \& Kolarić, 2016; Dragicevic, Tomasevic, Stanovic, \& Avejic, 2016; Russo et al., 2013), 'scattered hotels' (Scarcelli, 2017; Pollice, 2016; Fumo \& Feltria, 2012) and 'widespread hotels' (Monge, Cattaneo, \& Scillia, 2015). The majority of authors use the original Italian word: 'AD' (Ideass, n.d.; Verges Palazon, 2016; De Montis, Serra, Ledda, \& Ganciu, 2014; Valone \& Veglio, 2013; Dropulić, Krajnović \& Ružić, 2008). 'Difuzni hotel' is the official expression for AD in Croatia ('Pravilnik o razvrstavanju, kategorizaciji i posebnim standardima ugostiteljskih objekata iz skupine hoteli,' 2016). The corresponding expression for AD in the Slovene language is 'razpršeni hotel' (http://razprsenihotel.si; Blatnik, 2017). However, Slovenes translate the term in English as 'distributed hotel' (http://razprsenihotel.si) or 'diffusion hotel' (Blatnik, 2017). Those two terms are exceptions to the existing English-related literature on AD. In this paper, we use the original Italian term $\mathrm{AD}$ or $\mathrm{ADS}$ (for plural).

Scholars and practitioners define AD from different perspectives. $\mathrm{AD}$ is understood as a: 
- Tourist/hospitality model: a form of innovative tourist facilities and services (Dragicević et al., 2016), a new kind of hospitality (De Montis et al., 2014), a hospitality model (Vallone \& Veglio, 2013), an innovative form of hospitality (Ideass, n.d.), a hospitality concept (Dragicevic \& Letunic, 2015; Verges Palazon, 2016);

- Sub-type of hotel: new hotel model (Monge, Cattaneo \& Scillia, 2015), particular type of hotel (Ideass, n.d.), a new alternative to traditional TACS (Canfalonieri, 2011), emerging concept of hotel typology (Presenza, Yucelen \& Camillo, 2016), or

- Tourist accommodation management system (De Montis et al., 2014).

\section{Characteristics}

Dall'Ara (2015) defines an AD as an original model of hospitality and a model for tourism development of the territory. It is suitable for the 'third generation' of tourists who desire to experience a unique vacation, new and different places, personalised services, authenticity and want to immerse themselves in the local cultures and unique situations (Ideass, n.d., Dall'Ara, 2015; Verges Palazon, 2016). Dall'Ara thinks 'of an AD as a novel that tells the story of a culture. Guests are brought into the story temporarily, so they better understand the way of life' (Murphy, 2011).

An AD is characterised by its deep ties with the surrounding territory and the local culture; in fact, territory and culture are an integral part of its service (Vallone, Orlandini \& Cecchetti, 2013). It provides an experience of authentic life in a historical centre (or rural village) - 'network of "local flavour" houses, uninhabited and pre-existing, that are able to operate as a hotel' (Monge, Cattaneo \& Scillia, 2015, p. 69).

The innovation lies in the involvement of different tourism-related services that develop a form of hospitality under one coordinated management. They intend to valorise the potentialities of the area, e.g. culture, history, traditions, food products, scenery etc. with little impact to the environment. Despite having different owners, the unified management promotes the integrated service of the territory (Vallone \& Veg-
Table 1 Combination of Feelings in an AD

\begin{tabular}{|c|c|}
\hline Feeling at home & Feeling in a hotel \\
\hline Courtesy and kindness & $\begin{array}{l}\text { Provision of professional } \\
\text { services }\end{array}$ \\
\hline Authenticity & Efficiency \\
\hline Non-standardised rooms & Easy booking \\
\hline Local and warm furniture & $\begin{array}{l}\text { Variety of tariffs, according } \\
\text { to the different rooms }\end{array}$ \\
\hline Attention to details & Comfort \\
\hline Link with the territory & Wide range of services \\
\hline $\begin{array}{l}\text { Contacts with the local } \\
\text { residents }\end{array}$ & Contacts with other guests \\
\hline Informal environment & Privacy \\
\hline
\end{tabular}

Notes Adapted from Ideass (n.d., p. 4).

lio, 2013). An AD offers guests some typical hotel service, e.g. customer assistance, cleaning, food, beverage etc. (Dall'Ara, 2010) and promotes other activities e.g. selling of local products, storytelling, local guidance etc. Dragičević \& Letunić (2015) present an AD as a concept that connects small tourism providers in a specific small geographic area into a broader and more complete range of tourist services.

This new kind of hospitality is based on a network of houses built usually in a historic centre or in a village. The visitors have the opportunity to 'live the area' by taking part of the life in it while enjoying the comfort of a hotel (De Montis et al., 2014, p. 1).

A set of distinctive features enable an $\mathrm{AD}$ to establish itself on the tourist market as a competitive player (Vallone, Orlandini \& Cecchetti, 2013). It positions itself 'between the idea of [the] family house and traditional hotel accommodation' (Presenza, Yucelen \& Camillo, 2016, p. 226). Due to its features, an AD combines feelings of home and of hotel (see http://www .alberghidiffusi.it). A combination of both is presented in Table 1.

From a technical point of view, an $\mathrm{AD}$ is characterised by a horizontal framework, not a vertical one as in a traditional hotel. Its components are 'scattered' within different buildings in the same urban (rural) area; thus, it is not a typical condominium-like traditional hotel (see http://www.alberghidiffusi.it). The 
centre of an $\mathrm{AD}$ is located in the main building with reception and common spaces. In the inner lobby, the receptionist informs guest about activities in the are. Examples of local art and handicrafts reinforce the identity of the locality. A local urban centre, which guests feel to be a lively welcoming community, represents the outer lobby of an AD (Vallone, Orlandini \& Cecchetti, 2013). Accommodation units are scattered around the area within walking distance to the main building.

The characteristics of an AD can be summarised as (Central Europe Programme, 2013):

- Joint management;

- Presence of common areas for the hotel guests;

- Range of hotel services (cleaning, breakfast, reception, assistance to the guests);

- Presence of hosting community;

- Integration in the territory and in its culture;

- Honest environment;

- Reasonable distance between guest units and areas $(200-300 \mathrm{~m})$.

Ideass (n.d.) points out the following advantages of ADS. Firstly, an AD generates high-quality services in local areas and territories on a sustainable basis. There are no negative environmental impacts while existing houses are restored and networked, not newly built. They prevent the abandoning of historic centres. Furthermore, they help to develop and network the local tourist supply and increase sustainable tourism development in the off-the-beaten-track areas.

Promoting participation within the local communities is a particular benefit of ADs. Stakeholders in the local community become aware of the advantages of the image, social life, economic returns and preservation of the resources. Non-productive space of public administration can get a new function - common space for tourists. New events and new personal assistance services can be encouraged by local associations. The owner of houses starts to look at their property in a different manner. Local enterprises and the services sector (e.g. handicraft, food and fine sector) can use ADS as a means of increasing their revenues (ibid.).

This innovative form of hospitality can bring [...] sustainable development, triggering economic animation and providing opportunities for the balanced utilisation of the local resources and tourist potentials' (Ideass, n.d., p. 6). The guidelines of the AD model respect the value of sustainable development in many ways (Racin, 2012):

- Promote local culture (visitors select an AD to enjoy an authentic local experience);

- Stimulate the local economy (ADs encourage homeowners to participate in an organisation (sometimes a cooperative) and support the development of small business in traditional sectors, e.g. handicrafts, food preparation, other local products);

- Protect the environment (preserving existing buildings and giving them 'a new lease on life').

The organisational structure and ownership of ADS are not determined. An AD can be constituted through a private initiative (by one or more entrepreneurs) or in a coalition of the public and private sectors on the particular area (Confalonieri, 2011). Dropulić et al. (2008) point out three ownership structures:

- One owner (e.g. family, with special arrangements for rent with the owners of rooms and apartments);

- A commune as a hotel owner (e.g. 'community hotel', the Bethlehem experience - Pollice, 2016);

- Common rooms fund run by a cooperative.

For Ideass (n.d.), there are two major ways to create an $\mathrm{AD}$ :

- An investor purchases or rents the accommodation units and becomes the manager;

- A group of locals creates a consortium and delegate the management of the structure to a private subject, e.g. to the cooperative.

In the initial phase of creating an $\mathrm{AD}$, the local administration plays an essential role. Its priority is to 'incubate' the idea of the AD in the local area and support it, e.g. with the facilitation of the legal aspect, investments in local infrastructure, etc. It is deeply engaged in the first step in the path of creating an $\mathrm{AD}$ that continues with (Ideass, n.d.): 
- Territorial analysis (verifying the existence of conditions for creating an AD);

- Marketing analysis;

- Technical phase (preparing a sound business plan);

- Provision of start-up support (financing);

- Management.

The characteristics of the environment (the territorial ties and the influence of the local community on the structure), the characteristics related to the market or to the market segment, and the strategies implemented by the economic actors are the three most important classes of critical success factors for an $A D$ (Monge, Cattaneo \& Scillia, 2015; Vallone, Orlandini \& Cecchetti, 2013). However, all three critical success factors have value only if some basic determinants of territorial attractiveness exist: (a) the presence of a territorial network, (b) the sensitivity of the population to the management theme and (c) the legislation that allows the development of the initiatives (ibid.). Thus, there has to be 'a strong organic link between an $\mathrm{AD}$ and its territory;' an AD has to be connected to local characteristics (e.g. morphological, climate, wildlife, economic production etc.) and socio-cultural specific features that 'the flow of history has produced in that territory' (Vallone, Orlandini \& Cecchetti, 2013, p. 32).

It is necessary that a national (or regional) administration formally recognise an $\mathrm{AD}$ as a new type of hospitality and in this way enable it in legal and economic terms. Moreover, governments have to set up special financial schemes to support the creation and operation of ADs (Ideass, n.d.; Vallone, Orlandini, \& Cecchetti, 2013; Russo et al., 2013).

\section{Methodology}

The research was conducted in Slovenia from June to December 2017. For data collection and for data processing different qualitative methods were used that corresponded to the research goals.

Data were collected from primary and secondary sources. The following relevant secondary sources were used: scientific and professional articles, magazines, books, tourism-specific regulations in Italy and in
Slovenia, websites, media official pages and other materials. Data from primary sources were collected (a) during four in-depth semi-structured interviews and (b) during site-observations at AD Konjice, Slovenske Konjice. Site-observation helped us to collect additional data to examine specific relevant facts or to clarify the data collected with other methods.

To achieve the research goals, interviewees were sought to provide relevant information:

1. On strategy and on the legal framework on ADS in Slovenia;

2. On operational activities on ADS development in the state.

The results of the preliminary investigation on participants in interviews showed that there were four relevant people who were engaged in AD projects in Slovenia: two representatives of the government and two representatives of the TAC sector, who were involved in AD operational projects in Slovenia.

1. Secretary of State, responsible for tourism at the Ministry for Economics, Development and Technology (hereinafter MGRT). This interviewee was the most relevant participant to provide information on current and future regulatory framework on ADS in Slovenia.

2. Secretary of State in the Cabinet of the President of Government of Republic of Slovenia responsible for establishing a dialogue with civil society, for coordination of citizen initiatives and for social entrepreneurship (hereinafter Secretary of the State in Government). The interviewee has been involved in developing and implementing ideas about ADS in Slovenia from its beginning. He was also engaged in an operational phase of opening the first AD in Slovenia.

3. Two representatives of the private sector, involved in ADS in Slovenia: the project manager of the first AD in Slovenia (AD Konjice) and the initiator of another potential AD in Slovenia.

All four potential participants were asked to participate in this research, informed by the research goals and asked for permission to use their names. We sent them reminders with the pre-set interview-questions in advance. 
The research questions were adapted to the area of evolvement of each participant in the interview and designed to elicit answers to the research questions. Different open-ended questions were prepared for each participant (Table 2).

The interviews with the Secretary of the State in MGRT, with the Project Manager of AD Konjice and with the initiator of another AD in Slovenia were conducted by the author of the research in person at the interviewees' premises; however, the interview with the Secretary of the State in Government was conducted over the telephone. Each interview lasted an hour on average. The statements of the interviewees were documented in writing while the interview was being carried out. Particular attention was paid to make verbatim notes of the most interesting statements.

Data were processed by using the method of content analysis. For the first part of the results section, the method of description and compilation were used and in the second part, content analysis of data from semi-structured interviews. A part of the findings is presented in the interviewee's own words. Most often, their comments, answers and points of view are paraphrased. Observations, data and answers are interpreted and significant findings highlighted.

\section{Results}

Results of the research are presented in the parts of the section, following the answers to the research questions. In the first part, the results of the research on the evolution of $\mathrm{AD}$ in Italy in the last two decades are presented and in the second part the results of how the concept of $\mathrm{AD}$ has been transformed from an idea to the opening of the first AD in Slovenia. In the third subpart, the results highlight the organisational and legal framework for establishing an $\mathrm{AD}$ in Slovenia.

\section{Evolution of $A D$ in Italy}

The $\mathrm{AD}$ is an Italian concept that 'combines the very old with the contemporary' (Racin, 2012). It was originated in 1982 in Carnia, in the Italian Region Friuli Venezia Giulia. After the severe devastation of the territory caused by the earthquake in 1976, a technical working group aimed to restore and improve small centres. Giancarlo Dall'Ara, a professor of marketing, engineered a new hospitality model: AD (Ideass, n.d; Vallone \& Veglio, 2013).

Initially, the $\mathrm{AD}$ was thought to respond to the need of restoring houses in historic centres that were not attractive as tourist resources (Ideass, n.d.). In the following years, a model of the AD spread to others regions in Italy. As a form of 'distributed hospitality' A D have changed the perceptions of Italian tourist facilities and services (Dall'Ara, 2015). Differences among ADS that appear within the country are metaphorically described as 'artists' palettes with colours' (Dropulić et al., 2008, p. 610). In 2017, one of Italy's leading newspapers, La Republica, reported on 200 ADS in Italy. Only 76 reflected the idea of mixing preservation and hospitality; of those only 35 are officially accredited (see http://www.reidsitaly.com). The AD has been registered as a trademark valid at the European level (Ideass, n.d.).

Common aspects of an $A D$ are the following (see http://www.alberghidiffusi.it):

- 'Horizontal hospitality' (rooms and services located in different buildings);

- Buildings, located in culturally, historically, environmentally important territories;

- Typical food from the area;

- 'AD' Doc (the ideal concept);

- Centralised management;

- Hospitality unit;

- Location in historical centres;

- Integrated hosting community;

- Shared restrooms for the guests;

- Reasonable distances between housing units and common spaces;

- Original environment with typical houses (furnished and refurbished);

- High-quality standard (comparable to a threestar hotel or higher);

- Integration of the tourist in the area and the culture.

In 2012, the visitors of $A D S$ in Italy were foreign travellers (46\%); most of the guest were couples (55\%). 
Table 2 Set of the Questions Prepared for Each Interviewee for Semi-Structured Interview on AD in Slovenia

\begin{tabular}{|c|c|}
\hline Interviewee & Questions \\
\hline $\begin{array}{l}\text { Secretary of } \\
\text { State in MGRT }\end{array}$ & $\begin{array}{l}\text { How do you understand the implementation of ADS in Slovenia? } \\
\text { Is the government going to regulate ADS as a new type of TAC? }\end{array}$ \\
\hline $\begin{array}{l}\text { Secretary of } \\
\text { State in Gov- } \\
\text { ernment }\end{array}$ & $\begin{array}{l}\text { How has the idea of ADS evolved in Slovenia? } \\
\text { What are other initiatives in Slovenia referring to ADS, apart from the AD in Konjice? } \\
\text { What are key issues of the initial phase of the AD Konjice and potential other ADS in Slovenia? } \\
\text { What are the benefits of SE and cooperatives as organisational forms in the case of ADS in Slovenia? } \\
\text { How did the government support the establishing of AD Konjice and how it will support it in the future? }\end{array}$ \\
\hline $\begin{array}{l}\text { Project man- } \\
\text { ager of AD } \\
\text { Konjice }\end{array}$ & $\begin{array}{l}\text { How do you understand the implementation of ADS in Slovenia? } \\
\text { Is the government going to regulate ADS as a new type of TAC? } \\
\text { The Secretary of the State in the Government was asked the following: } \\
\text { What is general relationship/mood of the local inhabitancies toward AD Konjice? } \\
\text { What are the benefits of the current organisational form (cooperative) of AD Konjice? } \\
\text { What legal background is supposed to be used for regulating the relationship between AD Konjice and } \\
\text { those who would like to participate in ADs with their properties and other activities? } \\
\text { Was there a feasibility study or a business plan for AD Konjice made for checking its long-term financial } \\
\text { performance? } \\
\text { Who is supposed to work in AD Konjice and how will they be paid? }\end{array}$ \\
\hline $\begin{array}{l}\text { Initiator of } \\
\text { another AD in } \\
\text { Slovenia }\end{array}$ & $\begin{array}{l}\text { What benefits do you see in potential ADs? } \\
\text { What kind of organisational form would you choose for it? }\end{array}$ \\
\hline
\end{tabular}

Senior guests accounted for only $3 \%$ in the guest structure. The primary interest of $\mathrm{AD}$ guests were environment and nature, food and wine, and typical places. An average stay in an AD was 2.9 nights, and the average occupancy rate was $68 \%$. On average, 4.7 people worked in A D S, mostly Italians (75\%) (Presenza et al., 2016).

From the constitutive point of view, the majority of Italian ADs have been established by private entrepreneurial initiative, by individuals strongly rooted with the territory of their residence. Only in some cases, Ads were created from the impulse of a group of local actors (Russo et al., 2013).

Via the Code of Tourism, the Italian Government in 2011 (30 years after the creation of the idea of ADs) acknowledged $A D$ as a TAC type within the cluster of hotels and other forms of TAC ('Codice della normativa statale in terma di ordinamento e mercato del turismo,' 2011). According to this legislative decree, the $\mathrm{AD}$ is characterised 'by accommodation in separate buildings, close together, mainly located in historic centres and placed a short distance from a central building in which reception, concierge and other re- lated services are offered' (article 9). Apart from ADs, there are three other sub-types of hotels: Paese Albergo (Eng. village hotel), Residence Diffuso (eng. scattered residence) and Albergo Diffuso di Campagna (Eng. country AD) (Dall'Ara, 2015).

Regulation on ADs has been enacted by all Italian regional administrations; Sardinia was the first Italian region that issued a specific law on Ads, in 1998, Molise was the final one, in 2014 (De Montis et al., 2014). However, not all regulations are adequate and complete; Italian regional administrations have indicated a variety of requirements concerning ADS (De Montis et al., 2014):

- The minimum accommodation capacity in different forms, e.g. eight bedrooms, two independent buildings, thirty bedrooms etc.;

- Maximum distance from the central building and the rooms: ranging from $200 \mathrm{~m}$ to $1,000 \mathrm{~m}$;

- Contextual aspects of AD design: an AD can be realised under certain circumstances - locations are limited to the municipalities with maximum 5,000 inhabitants, in historic centres with maxi- 
mum 3,000 inhabitants, an AD can be extended to inter-municipal areas.

National Association of Scattered Hotels (Associazione Nazionali Albergi Diffusi - ADI), established in 2006, promotes and supports the development of ADs in Italy, protects its image and its public reputation. One of the founders of the ADI and its president is the 'father of the AD model,' Dall'Arra (see http:// www.alberghidiffusi.it). International School specialising in ADS is the only school specialised in ADS and 'spread hospitality industry;' it operates within the framework of ' $4 \mathrm{E}$ development model:' Effectiveness, Efficiency, Equity, Ecologic sustainability (see http:// www.sisad.it).

In 2008, the United Nations Development Programme convention in Budapest gave Dall'Ara's concept of ADS an award for best economic growth practice capable of being transmitted to other countries (Ideass, n.d.). In 2010, Dall'Ara received the World Travel Market Global Award in London, given yearly to original thinkers in the tourism industry (Fumo \& Feltira, 2012).

AD in Italy is understood as a sub-type of hotel that is distinct from a traditional hotel. A hotel is - from the users' point of view - 'an institution of commercial hospitality, which offers its facilities (rooms, public areas, restaurants, bars, meeting rooms, recreation facilities) and services for sale' (Medlik \& Ingram, 2000, p. 13). It is a functional facility under common management, which has - in most cases - a similar physical structure: public space for accepting guests, hotel rooms/accommodation units - usually on the floors - and service area for staff (Cho \& Sparrowe, 2000). Traditional hotels usually have a vertical scheme. ADS, however, are characterised by a horizontal framework; in a traditional hotel, reception, public spaces and accommodation units are usually placed within one building; in ADS, those parts have different locations within a specific area (De Montis et al., 2014).

The critical difference between ADS and traditional hotels and private TACs is the symbiotic relationship' of the tourist facilities and services within the area of ADS; an AD contributes to the growth of the whole area, while traditional hotels and private
TACs mostly focus on their own profit (Dropulić et al., 2008).

For Pollice (2016), private investors in a traditional TAC usually create a model of tourism that has nothing to do with the typical characteristics of the place; moreover, it reduces the quality of the landscape and environment. ADS - in contrast to traditional TACS have a more sustainable note.

The role of a hotelier in an AD overlaps with the role in a traditional hotel structure. However, the significant differences lie in the style of management and in the importance attributed to the overall performance. Instrumental benefits in $\mathrm{ADS}$ are essential and distinctive elements of the hospitality system (Valone et al., 2013).

Service excellence for ADS is different from traditional hotels (Vallone \& Veglio, 2013). The high quality of an $A D$ is derived from innovative services, e.g. friendly staff, the integration of tourists and the local community, cultural and artistic events, traditional rooms, local wine and food etc. It offers an original atmosphere of hospitality and ties with the territory; it is designed to encourage guests to have contact with residents of the community and in this way become a 'temporary residents.' An A D guest has diverse options to buy local products and participate in local events. Thus, the AD is characterised by the elasticity of the services, which is not typical for traditional hotels. Furthermore, guests of ADS are more willing to accept some negative aspect of ADS than guests in traditional hotels are, e.g. small rooms and bathrooms, steep steps, no internet connection, etc. (Vallone \& Veglio, 2013).

Some significant differences between Ads on one side and traditional hotels and private TAC on the other are summarised in Table 3.

\section{$A D s$ in Slovenia: From the Initial Idea to the First $A D$}

Since 2010, the Association of Municipalities and Towns of Slovenia has been seeking interesting business solutions and models in tourism. In 2012, the case of the revitalisation of Bale in Istria, Croatia, and its tourist transformations rose attention at the summit on social entrepreneurship in Slovenske Konjice ( $\mathrm{T}$. Slapnik, personal communication, 8 December 2017). 
Table 3 Differences between ADs, Traditional Hotels and Private TAC

\begin{tabular}{llll}
\hline Item & ADs & Traditional hotels & Private TAC \\
\hline Number of premises & Three or more & One & One or more \\
Reception & In the area & In hotel & On proprietors' home \\
Location of acc. units & Spread in the area & Single location & Single location or spread \\
Furniture & Traditional & Standardised/modern & Standardised/modern \\
Services & Professional & Professional & Self-service \\
Connection with & The locals & Other hotel guests & The locals \\
Type of experience & Exploration & Holidays/relaxation & Holidays/relaxation \\
Influence of environment & Very important & Not important & Not important \\
Seasonality & Not important & Partly important & Partly important \\
Location & Rural areas, villages & Cities, urban areas & Small towns, suburbs \\
Cooperation of locals & Very important & unimportant & unimportant \\
Guest structure & Middle-age or senior indi- & Couples, families & Individuals, couples, families \\
viduals and couples & of all ages & of all ages
\end{tabular}

Notes Adapted from Črnigoj Marc (2016, p. 21).

The same year, Mrak, Zavodnik, and Fikfak (2012) presented an Italian AD model as a solution for the revitalisation of rural countryside in the Slovenian Alps.

The government of Slovenia started supporting ADS in the context of the development of social entrepreneurship and cooperatives. The governmental working group organised several presentations about best practices of ADS in Italy and Croatia for Slovenian municipalities, who showed interest in ADS (e.g. Municipalities of Piran, Koper, Bohinj, Slovenske Konjice, etc.) (T. Slapnik, personal communication, 8 December 2017). In 2015, Over 50 interested representatives of Slovene municipalities (predominantly from Istria, some from Styria, Prlekija, and Gorenjska) visited ADS in the Friuli-Venezia Giulia and experienced how cooperatives can successful in rural areas (see https://skupnostobcin.si).

Piran has been intensively developing initiatives for establishing tourist cooperatives and consequently ADS. In 2011, The municipality of Piran, together with the organisers of excursions, formulated the concept of 'tourist experience' in Padna. The village community and some of its inhabitants developed attractive services and facilities. As there were vacant premises that needed reconstruction, the local community and municipality planned to connect them in ADS and devote them to tourism (Širok, 2016). In 2016, the conceptual architectural design of ADS was prepared (Černigoj Marc, 2016). The initial idea was to include all providers in the village in ADS; an AD should be managed as a cooperative. The investment of the first phase of the renovation was estimated at one million euros (Širok, 2016). Thus, Padna had all the major foundations for creating ADS: an excellent location, the locals and municipality who supported ADS, and 34 available beds for tourists. It was foreseen that the first AD would be created there. However, by the end of 2017, the plans had not been realised.

Parallel to the development of ADs in Padna, some of the Slovenian Local Action Groups (L As - Between Snežnik and Nanos, Istria, from Pohorje to Bohor, Gorenjska Košarica, Soča Valley, Dolenjska and Bela Krajina, Barje) joined the project of cooperation under the name 'Pilot Model of an AD' (Društvo Podeželje, 2017). Through projects of participation in the LAS, local partnerships can carry out projects in the entire territory of Slovenia. The first phase is dedicated to joint activities for the preparation of the $A D$ model and the implementation of motivational activities for obtaining the locations of individual hotels in the field of partner LAS. In the second phase, the project will include the implementation activities of the AD at se- 
lected locations (U. Buda, personal communication, 20 July 2017). The relationship between partners is planned on an entrepreneurial basis.

The project aims to establish the conditions for the establishment of ADs in Slovenia and a business system that would connect Slovenian ADs into a joint story or joint offer (U. Buda, personal communication, 20 July 2017). Due to various problems, the project is expected to start in 2018 (Društvo podeželje, 2017). Tavčar (2017) defines this type of ADS as a Slovenian alternative to Airbnb, but with a significant difference: the organisers will take a much lower commission for their work than specified by Airbnb. By using and marketing existing tourist accommodation capacities in Slovenia, it would not be necessary to build many new hotels. This approach is in line with the European Circular Economy (CirCE) project that covers tourism, waste, and mobility (Tavčar, 2017). A proposal for an action plan for the transition to a circular economy, prepared by the government of Slovenia in 2017, is expected to be implemented in 2018 (T. Slapnik, personal communication, 8 December 2017).

In 2016, four municipalities in Štajerska: Slovenske Konjice, Vitanje, Oplotnica and Zreče decided to join their tourism development in the Rogla-Pohorje destination. In April 2016, the Cooperative Konjice announced the plan for the creation of an AD at the end of the year (Mernik, 2017).

On December 15, 2017, the first AD in Slovenia was opened: AD Konjice (Novice.si, 2017). The central location of AD Konjice is in Trebnik Castle on the outskirts of the town of Slovenske Konjice. There is a reception in the building (reception can also be 'virtual'), breakfast room and six rooms of the three-star category. In accordance with the Social Entrepreneurship Act ('Zakon o socialnem podjetništvu', 2011), those rooms are rented free-of-charge for the following three years from the Municipality of Slovenske Konjice. The remaining five accommodation units are located in Dravinja Ranch, which joined the AD immediately after its opening (Novice.si, 2017). In continuation, new locations in Rogla-Pohorje destination will gradually be added to the AD. In presentation workshops on ADS in the above-mentioned four municipalities, the interest of property owners and other tourist suppli- ers for joining ADs has already been expressed. Due to the positive orientation of the local population to ADS, there are expected to be at least 50 beds available in the AD Konjice by the end of 2018 (J. Ivanuša, personal communication, 27 December 2017).

In the first phase, the key issue of AD Konjice is a single-entry site for future visitors of Pohorje-Rogla; this site enables them to choose the location of their residence and other activities in the destination only in one entry point (T. Slapnik, personal communication, 8 December 2017). Accommodation units of AD Konjice are marketed and can be booked through online platforms. The price of a room with breakfast starts at $€$ €० (see http://razprsenihotel.si).

Before the opening, the initiators of AD Konjice were closely linked by volunteering work, enthusiasm and confidence in the AD's success. In the startup phase, they did together everything that needed to be done in a given situation. 'When it was necessary to clean, we all cleaned; when it was necessary to do the administration, we did it jointly' (J. Ivanuša, personal communication, 27 December 2017). After opening the $\mathrm{AD}$, operational (booking, reception of guests) and the managerial function was contracted to the associate member AD. By the end of 2018, at least one person should be employed (J. Ivanuša, personal communication, 27 December 2017).

For the start-up phase of AD Konjice, the cooperative obtained $\mathrm{a} € 20$, 000 grant from the European Regional Development Fund (Operational Program for the Implementation of Cohesion Policy in 2014-2020). The tender document of cooperative contained some elements of traditional business plans; however, there were no financial projections to justify the economic performance of the AD. In cooperatives, positive results of their operation are usually assessed by other dimensions, not only by financial measures; moreover, there is no short-term success (J. Ivanuša, personal communication, 27 December 2017).

AD Konjice is organised as a cooperative. The proprietors of TACS can engage in cooperative as a member or as a 'landlord.' In the first case, the proprietor can become the member of the cooperative and market their TAC through AD; for its service, the cooperative charges them the agreed fee. The second way 
(but not the preferable one) is that the Cooperative rents and manages the proprietors' TAC (T. Slapnik, personal communication, 8 December 2017).

Slapnik (personal communication, 8 December 2017) is convinced that further development and performance of AD Konjice will be significantly influenced by two key factors: by AD management and by the willingness of property owners in the destination to include their premises in the AD. The manager of AD Konjice is supposed to be a person with experience in tourism, a visionary who will be convinced in the development of the $\mathrm{AD}$. The manager will also have to coordinate the activities between all cooperative stakeholders and guests. The most desirable personal characteristics of the manager-coordinator of A D Konjice are a friendly/warm attitude toward stakeholders, hospitality, and empathy (J. Ivanuša, personal communication, 27 December 2017).

According to Slapnik (personal communication, 8 December 2017), the willingness of the local population to include their real estate in AD Konjice can become a severe issue; it is partially related to the traditional attitude of Slovene population to real estate. Being a property owner for Slovenians still represents a certain status. However, Slapnik assumes that the new socio-economic conditions (aging of the population, inability to maintain real estate, tax policy, etc.) will trigger a change in the attitude of the local population in the Rogla-Pohorje area to their unused real estate, i.e. 'dead capital.'

The Rogla-Pohorje destination offers a good potential for the success of AD Konjice. It is up to public and private actors in the territory to decide how they will exploit the available potential. In any case - success or failure - AD Konjice will become an example for other ADS in Slovenia (T. Slapnik, personal communication, 8 December 2017).

\section{Organisational and Legal Framework for ADs}

in Slovenia

Cooperatives are regulated by a special law ('Zakon o zadrugah', 2009). Cooperatives 'combine the positive features of corporate governance with what is good for the community' and that is their advantage over corporate organisational forms (T. Slapnik, personal com- munication, 8 December 2017). In commercial companies, e.g. limited liability companies, shareholder corporations, etc. ('Zakon o gospodarskih družbah, 2009) there is more focus on the owners than on guests. In cooperatives, however, the personal ownership puts the personal relationship with the guest in the first place.

The key regulation on hospitality in Slovenia, the Hospitality Act ('Zakon o gostinstvu,' 2007), does not define ADS as a special type of TAC. Similarly, there are no regulations about ADS in both by-laws: Rules on Minimum Technical Conditions and The Minimum Level of Hospitality services ('Pravilnik o minimalnih tehničnih pogojih in o minimalnem obsegu storitev za opravljanje gostinske dejavnosti,' 2017) and the Rules on the Categorisation of Accommodation Facilities ('Pravilnik o kategorizaciji nastanitvenih obratov', 2008). Moreover, ADs are overlooked even in the new Strategy for the Sustainable Growth of Slovenian Tourism from 2017 to 2021 (Ministrstvo za gospodarski razvoj in tehnologijo, 2017). For the government representatives responsible for tourism, ADS were (in July 2017) an 'expression' for a new type of tourist service that links private TAC owners; there was no plan to propose the Government of Rs to change the tourist regulations because of it (E. Štravs Podlogar, personal communication, 14 July 2017).

The absence of a legal determination of ADs has not been an obstacle to the applicants for obtaining E U grants for AD purposes. In the Rural Development Program for the period of 2014 to 2020, there are several measures that are suitable for ADS: a village renewal measure in rural areas, support for pilot projects and the development of new products, practices, processes and technologies, support for local development under the LEADER initiative (Local Community Leadership - LAS) etc. (Ministrstvo za kmetijstvo, gozdarstvo in prehrano, 2017). Within the programs that include an AD model applicants can compete for the funds.

Successful operation of ADS in Slovenia, particularly on a cooperative basis, is also supported by various nongovernmental organisations. In the middle of 2017, the Manual for ADS was published (Škofljič Vrbica, 2017). In November of the same year, the first 
free motivation workshop on ADS was held (Podjetniški portal, 2017).

Slapnik (personal communication, 8 December 2017) believes that the legal framework for ADS as a TAC type in Slovenia at the present stage is not a necessary condition for the further development of ADS on the tourist market. However, if A Ds will prove to be a successful hospitality model, Slovenia should follow the practice of Italy and Croatia and formally define them.

\section{Conclusion}

The results of this research show the evolutionary path and organisational and legal framework of ADS in Italy and Slovenia.

In Italy, the concept of AD appeared in the 1980s. ADs been spread over the country since then and have been developing for over three decades. At present, $\mathrm{AD}$ is determined by the Italian regulations as a subtype of hotel. Specific characteristics differentiate it from other tourist accommodations: horizontal structure, scattered facilities around the area (but with joint management), different hospitality approach, close ties with the territory, heritage and community and flexible tourism-related services. Additionally, ADs in Italy usually support the sustainable development of the territory. ADs have changed the view of Italian hospitality. The legislative context, a national organisation, a special school and trademark protection attempt to direct their development path. However, in practice, their diversity is a consequence of different regional regulations and characteristics of the territory, natural heritage and local community.

In Slovenia, the idea of establishing the ADs have started after 2010 through a public initiative (in the context of fostering social entrepreneurship and cooperatives). In 2016 and 2017, two mainstream development directions of ADS appeared: (a) integration of various entrepreneurial initiatives into the $\mathrm{AD}$ framework (e.g. the LAS project), and (b) creation of an AD as a cooperative (e.g. AD Padna, AD Konjice). The first example of an AD model aims to connect providers of various tourist services in Slovenia and to ensure a higher flow of tourists among them. The second example of an AD model aims to connect mem- bers (TAC proprietors or providers of other tourist services) in cooperatives. Several initiatives in Slovenia promote the second model. The first AD in Slovenia, which opened in December 2017, was A D Konjice (Slovenske Konjice, Rogla-Pohorje destination). The characteristics of the territory (destination) and support of the local community offer a good potential for its successful long-term performance. However, as a 'newcomer' in the TAC sector, it is expected to be faced by some administrative barriers (of legal nature) and issues (future funding, management, engagement of proprietors of TACs, etc).

The key finding of this research is that the implementation of ADS in Slovenia is not supported by the current tourism policymakers; however, the case of ADS in Italy indicates that ADS have more potential for development with the support of the local and the state policymakers than without it. Thus, further research is necessary to investigate the performance of the first AD in Slovenia, to follow the pace of appearance of new ADS in Slovenia in the future and potential changes in attitudes of the government toward ADs.

There are certain limitations to this research. Firstly, there was a limited scope of available literature on ADs. Secondly, there was a limited number of people in Slovenia who were engaged in ADs development projects and could participate in the research. Thus, the number of interviewees was only four. Despite the fact, that they were the relevant participants who could provide qualitative answers about ADS in Slovenia, more participants in the research could have revealed new perspectives on the topic. We hope to overcome those limitations in further research.

\section{References}

Blatnik, J. (2017, October). Razpršeni (difuzni) hotel. Paper presented at the conference Trendi in izzivi v živilstvu, prehrani, gostinstvu, turizmu izobraževanju in usposabljanju, Ljubljana, Slovenia.

Canfalonieri, M. (2011). A typical Italian phenomenon: The 'albergo diffuso.' Tourism Management, 32(3), 685-687.

Cerović, Z. (2010). Hotelski menadžment (2nd ed.). Opatija, Croatia: Fakultet za turistički i hotelski menadžment Sveučilišta u Rijeci.

Cho, K. S., \& Sparrowe, R. T. (200o). Welcome to hospitality: 
An introduction (2nd ed.). Albany, Ny: Delmar Thompson Learning.

Črnigoj Marc, T. (2016). Razvoj Istrskega podeželja: primer vzpostavitve razpršenega hotela in možnost obnove vasi Padna (Unpublished master's thesis). University of Ljubljana, Ljubljana.

Dall'Ara, G. (2010). Manuale dell'albergo diffuso: l'idea, la gestione, il marketing dell' ospitalita diffuso. Milan, Italy: Franco Angeli.

Dall'Ara, G. (2015). Manuale dell'albergo diffuso: l'idea, la gestione, il marketing dell' ospitalita diffuso (2nd ed.). Milan, Italy: Franco Angeli.

Central Europe Programme. (2013). Diffused hotel: A model to develop tourism through innovation and tradition. Retrieved from http://www.central2013.eu/fileadmin/user _upload/Downloads/outputlib/Custodes_Diffused _Hotel_Model.pdf

Codice della normativa statale in tema di ordinamento e mercato del turismo. (2011). Gazzetta Ufficiale, No. 129.

De Montis, A., Serra, V., Ledda, A., \& Ganciu, A. (2014, July). Recovery of rural centres and 'Albergo Diffuso:' A case study in Sardinia, Italy. Paper presented at the International Conference of Agricultural Engineering, Zurich, Switzerland.

Dragicevic, M., \& Letunic, S. (2015). Diffuse hotels in the function of creating augmented agricultural households tourist offer based on innovations. Procedia: Economics and Finance, 32, 437-441.

Dragicevic, M., Tomasevic, A., Stanovic, N., \& Avejic, I. (2016). The managers' attitude towards diffuse hotels as innovative from of agricultural households tourist offer. Procedia: Economics and Finance, 39, 102-107.

Dropulić, M., Krajnović, A., \& Ružić, P. (2008). Difuzni hoteli: jedno od rešenja za održivi razvoj turizma. In V. Rajkovič, E. Jereb, T., Kern, M. Kljajić, M. Pagon, \& G. Vukovič (Eds.), Knowledge for sustainable development: Proceedings of the 27th International Conference on Organisational Science Development (pp. 601-617). Kranj: Moderna organizacija.

Društvo podeželje. (2017, 6 November). Kako v Sloveniji vzpostaviti zadružni razpršeni hotel in urediti skupnostni vrt. Retrieved from http://www.drustvo-podezelje.si /zgodbe/item/501-kako-v-sloveniji-vzpostaviti -zadruzni-razprseni-hotel-in-urediti-skupnostni-vrt

Fumo, S., \& Feltria, S. (2012, 30 July). Stattered hotels, a 'Made in Italy' of-beat experience. Retreived from http: //albergo-diffuso.blogspot.it/2012/o7/scattered-hotels -made-in-italy-offbeat.html

Idwass. (n.d.). Albergo diffuso: Developing tourism through innovation and tradition. Retrieved from http://www .stratech.it/uploads/AlbergoDiffusoENG.pdf

Medlik, S., \& Ingram, H. (200o). The business of hotels (4th ed.). Oxford, England: Butterworth-Heinemann.

Mernik, J. (2017, 6 April). Več ponudnikov s skupno recepcijo. Novice, p. 14.

Ministrstvo za gospodarski razvoj in tehnologijo. (2017). Strategija trajnostne rasti slovenskega turizma 2017-2021. Retrieved from http://www.mgrt.gov.si/fileadmin/mgrt .gov.si/pageuploads/12-12-2017-KONCNO _STRATEGIJA_TURIZEM_popravek_za_splet_9.10 .2017.pdf

Ministrstvo za kmetijstvo, gozdarstvo in prehrano. (2017). Program razvoja podeželja Republike Slovenije 20142020. Retrieved from https://www.program-podezelja .si/sl/knjiznica/161-brosura-program-razvoja-podezelja -2014-2020/file

Monge, F., Cattaneo, D., \& Scilla, A. (2015). The widespread hotel: New hotel model for business tourist. Journal of Investment and Management, 4(1-1), 69-76.

Mrak, G., Zavodnik, A., \& Fikfak A. (2012). Turizem in poselitveni vzorci na podeželju na primeru razvoja poselitve v Slovenskih Alpah. A R, 12(1), 31-41.

Murphy, M. (2011, September). The towns Italy forgot. Retrieved from https://www.nationalgeographic.com/ travel/italy-hotels-traveler/

Novice.si. (2017, 15 December). V Slovenskih Konjicah odprli prvi razpršeni hotel. Retrieved from https://novice.si/ page/v-slovenskih-konjicah-odprli-prvi-razprseni -hotel/

Page, S. J., \& Connell, J. (2014). Tourism: A modern synthesis (4th ed.). Andover, England: Cengage Learning.

Podjetniški portal. (2017, 14 November). Brezplačna delavnica - 'Kako v Sloveniji vzpostaviti zadružni razpršeni hotel.' Retrieved from https://www.podjetniski-portal.si/ index.php?t=Event\&id $=15111$

Pollice, F. (2016). Community hotels: A model of territorial empowerment. Retrieved from http://www.univeur.org/ cuebc/downloads/TdC25_Community\%2ohotel\%2Oa \%2omodel\%2oof\%2oterritorial\%2oempowerment.pdf

Pravilnik o kategorizaciji nastanitvenih obratov. (2008). Uradni list Republike Slovenije, No. 62.

Pravilnik o minimalnih tehničnih pogojih in o minimalnem obsegu storitev za opravljanje gostinske dejavnosti. (2017). Uradni list Republike Slovenije, No. 35.

Pravilnik o razvrstavanju, kategorizaciji i posebnim standardima ugostiteljskih objekata iz skupine hoteli. (2016). Narodne novine, No. 56.

Presenza, A., Yucelen, M., \& Camillo, A. (2016). Passion 
before profit in hospitality ventures: Some thoughts on Lifestyle Entrepreneur and the case of 'Albergo Diffuso.' Sinergie, 34(99), 221-239.

Racin, A. (2012, 12 January). Albergo diffuso: An alternative form of hospitality. Retrieved from http:// tourismintelligence.ca/2012/o1/12/albergo-diffuso-an -alternative-form-of-hospitality/

Russo, G., Lombardi, R., \& Mangiagli, S. (2013). The tourist model in collaborative economy: A modern approach. International Journal of Business and Management, 8(7). Retrieved from https://doi.org/10.5539/ijbm.v8n7p1

Scarcelli, R. (2017, 5 August). Turning Switzerland's tiniest municipality into a hotel. Retrieved from https://www .swissinfo.ch/eng/albergo-diffuso_turning-switzerland -s-tiniest-municipality-into-a-hotel/43393508

Širok, L. (2016, 5 July). V Padni nastaja prvi razpršeni hotel. Retrieved from http://www.rtvslo.si/radiokoper/zgodbe/ v-padni-nastaja-prvi-razprseni-hotel-v-sloveniji/397429

Škofljič Vrbica, S. (2017). Priročnik za postavitev zadružnega razpršenega hotela. Ljubljana, Slovenia: Pravno-informacijski center nevladnih organizacij.

Tavčar, B. (2017, 4. July). Razpršeni hoteli so lahko rešitev, da gredo turisti tudi na podeželje. Retrieved from http:// www.delo.si/novice/okolje/nastaja-model-slovenskega -airbnb.html

Vallen, G. K., \& Vallen, J. J. (2013). Check-in check-out: Managing hotel operations (9th ed.). Upper Saddle River, NJ: Pearson Prentice Hall.
Vallone, C., Orlandini, P. \& Cecchetti, R. (2013). Sustainability and innovation in tourism services: The albergo diffuso case study. Eurasian Journal of Social Sciences, 1(2), 21-34.

Vallone, C., \& Veglio, V. (2013, August). 'Albergo Diffuso' and customer satisfaction: A quality service analysis. Paper presented at the 16th Toulun-Verona Conference 'Excelence in Services,' Ljubljana, Slovenia.

Verges Palazon, J. (2016). Albergo Diffusso: The silent awakening of rural Italy; Identifying key features and treshing main impacts (Unpublished master's thesis). University of Girona, Girona.

Zakon o gospodarskih družbah (zGD-1). (2009). Uradni list Republike Slovenije, No. 65.

Zakon o gostinstvu (zGos). (2007). Uradni list Republike Slovenije, No. 93.

Zakon o socialnem podjetništvu (zsocp). (2011). Uradni list Republike Slovenije, No. 20.

Zakon o zadrugah (zzad). (2009). Uradni list Republike Slovenije, No. 97.

Županović, I. (2015). Restructuring of the integrated tourism product as a basis of tourist destination sustainability: Kotor case. Tourism in Southern and Eastern Europe, 3, 503-522.

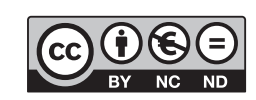

This paper is published under the terms of the Attribution- NonCommercial-NoDerivatives 4.0 International (CC BY-NC-ND 4.0) License. 